\title{
Rubidium recovery using potassium cobalt hexacyanoferrate sorbent
}

Tanjina Nur, Gayathri Naidu, Paripurnanda Loganathan, Jaya Kandasamy, Saravanamuthu Vigneswaran*

Centre for Technology in Water and Wastewater, Faculty of Engineering and Information Technology, University of Technology Sydney, Broadway, Sydney NSW 2007, Australia; emails:

Tanjina.Nur@uts.edu.au (T.N.); Gayathri.Danasamy@uts.edu.au (G.D.); pari.loganathan@yahoo.com (P.L.); jaya.kandasamy@uts.edu.au (J.K.); Saravanamuth.Vigneswaran@uts.edu.au

*Corresponding author: Tel +61-2-9514-2641; Fax +61-2-9514-2633; Email: Saravanamuth.Vigneswaran@uts.edu.au

\begin{abstract}
Rubidium is a highly valued and economically important metal present in large quantities in many natural and waste waters. However, its recovery is hampered by its low concentration and extracting agents' limited selectivity. A batch sorption study showed that a potassium cobalt hexacyanoferrate (KCoFC) sorbent had much higher sorption capacities for $\mathrm{Rb}$ and $\mathrm{Cs}$ than for $\mathrm{Li}, \mathrm{Na}$, and $\mathrm{Ca}$. Equilibrium sorption data at $\mathrm{pH} 7$ and $24 \pm 1^{\circ} \mathrm{C}$ for $\mathrm{Rb}$ and $\mathrm{Cs}$ satisfactorily fitted to the Langmuir model with sorption maxima of 96 and $61 \mathrm{mg} / \mathrm{g}$, respectively. A fixedbed column (12 cm height) containing a mixture of $2.2 \mathrm{~g} \mathrm{KCoFC}$ and $19.8 \mathrm{~g}$ granular activated carbon $(\mathrm{GAC})$ had a breakthrough sorption capacity of $61 \mathrm{mg} / \mathrm{g}$ when a solution containing 5 $\mathrm{mg} \mathrm{Rb} / \mathrm{L}$ was passed through the column at a velocity of $2.5 \mathrm{~m} / \mathrm{h}(0.7 \mathrm{~L} / \mathrm{h})$. When 1 and $5 \mathrm{mg}$ $\mathrm{Cs} / \mathrm{L}$ were added to the $\mathrm{Rb}$ solution, $\mathrm{Rb}$ sorption capacity dropped to 46 and $41 \mathrm{mg} / \mathrm{g}$, respectively. During $\mathrm{Rb}$ sorption, $\mathrm{K}$ from the $\mathrm{KCoFC}$ lattice was released. Leaching the column containing sorbed $\mathrm{Rb}$ with $0.1 \mathrm{M} \mathrm{KCl}$ for $60 \mathrm{~min}$ at a velocity of $10 \mathrm{~m} / \mathrm{h}$, desorbed $99 \%$ of sorbed $\mathrm{Rb}$. A process for recovering $\mathrm{Rb}$ from sea water reverse osmosis brine is presented.
\end{abstract}

\section{Introduction}


Rubidium $(\mathrm{Rb})$ has been widely utilised in many industries such as the manufacture of solid-state lasers, phosphors, photoelectric cells, and components of electrolytes for fuel cells [1-3]. It is also used as an additive in the form of rubidium carbonate to produce some special glasses utilised in fibre optics, telecommunication systems and night-vision devices [4]. Moreover, it has important applications in pharmacy and medicine, especially soporifics and sedatives and the treatment of epilepsy [3,5-6]. Because of the numerous applications of $\mathrm{Rb}$ in science, technology, and medicine and its low extractability from natural systems and wastes, the demand for and price of $\mathrm{Rb}$ in recent decades have increased in the international market [710]. For example the price for $100 \mathrm{~g}$ of $\mathrm{Rb}$ rose from US\$998 in 2001 to US\$1283 in 2010 $[2,9]$.

Generally, apart from existing in ore minerals, $\mathrm{Rb}$ is also found in salt lakes, sea water, geothermal water, and rejected brines from desalination plants and oil fields. It usually coexists with other metals such as cesium $(\mathrm{Cs})$, lithium $(\mathrm{Li})$, calcium $(\mathrm{Ca})$, sodium $(\mathrm{Na})$, magnesium $(\mathrm{Mg})$ and potassium $(\mathrm{K})$ in widely distributed liquid resources. Extraction of $\mathrm{Rb}$ is much more difficult than other alkali metals due to its low concentration, although $\mathrm{Rb}$ is more abundant than Cs (Table 1). Despite the concentration of $\mathrm{Rb}$ being small compared to other metals, it still has an economic value higher than that of other metals. Of the metals found in the sea water reverse osmosis concentrate (SWROC), only the price of Cs is higher than that of $\mathrm{Rb}$ (Table 1). However, the concentration of $\mathrm{Cs}$ is 250 times smaller than that of $\mathrm{Rb}$, which makes the potential benefit of extracting $\mathrm{Rb} 177$ times greater than that of $\mathrm{Cs}$.

Table 1

List of valuable elements economically extractable from sea water reverse osmosis concentrate 
(brine) (adapted from Petersková et al. [11]).

\begin{tabular}{ccccccc}
\hline & $\mathrm{Na}$ & $\mathrm{Mg}$ & $\mathrm{Li}$ & $\mathrm{Rb}$ & $\mathrm{Cs}$ & $\mathrm{U}$ \\
\hline & & & & & & \\
Concentration in brine $(\mathrm{mg} / \mathrm{L})$ & 27,520 & 2450 & 0.27 & 0.19 & 0.0008 & 0.0039 \\
Price $(\$ / \mathrm{kg})$ & 0.10 & 2.21 & 1.37 & 8802 & 12078 & 78.73 \\
\hline
\end{tabular}

Due to the low concentration, limited selectivity of extracting agents and complexity of brines, it is difficult to extract $\mathrm{Rb}$ from solutions. The methods currently available for extracting $\mathrm{Rb}$ include sorption, evaporation, precipitation, use of emulsion membranes and liquid-liquid extraction techniques $[12,13]$. Of these applications, ion exchange and sorption are the most widely used $[14,15]$. One of the main problems encountered in most studies on the sorption of $\mathrm{Rb}$ is that they mostly focused on its sorption from solutions containing only $\mathrm{Rb}$. They did not consider solutions containing a mixture of metals where there may be competition between metals for sorption $[14,15]$. To remove alkali metals from solution, different types of sorbents such as clay materials [16], Prussian blue [17], potassium metal hexacyanoferrate [11,18], zeolite [19], titanium dioxide [20], and ammonium molybdophosphate [21] had been used. All of these sorbents revealed a high capacity to remove Cs from nuclear waste brine with varying degrees of success. Very few studies have been reported on these sorbents for the extraction of $\mathrm{Rb}[11,15,22]$. Previous studies have shown that potassium metal hexacyanoferreate had high sorption capacity for $\mathrm{Rb}$ compared to other sorbents. Most of these studies were conducted using high concentrations of $\mathrm{Rb}(20$ to $>500 \mathrm{mg} / \mathrm{L}$ ) in batch experiments and only a few had been reported in fixed-bed systems [22]. Consequently the results of these studies with high concentrations would not be relevant for extracting $\mathrm{Rb}$ when present in relatively low concentration in natural resources such as SWROC (e.g. $0.19 \mathrm{mg} / \mathrm{L}$, Table 1).

Generally, batch experiments conducted on Rb sorption do not provide information about the hydrodynamic parameters of fixed-bed columns such as the dispersion coefficient [23]. 
Another drawback is their discontinuity and the need to perform complicated phase separation operations. Fixed-bed column experiments, on the other hand, do not have the above drawbacks, and the results of such experiments can be directly applied to: firstly, obtaining reliable solutions to design optimisation; and secondly, predicting the breakthrough curves of fixed bed columns in real-life scenarios. Desorption of the sorbed $\mathrm{Rb}$ and recovering it as $\mathrm{Rb}$ salts is easier when sorption experiments are conducted in column mode. Despite the numerous advantages of column mode sorption experiments, a major problem encountered is that using finely divided materials such as potassium metal hexacyanoferrate can cause the columns to clog. This can lead to pressure head loss. However, this problem can be overcome by either encapsulating the material on a coarser material [24,25] or physically mixing it with a coarser material such as granular activated carbon (GAC) [26].

The long-term broad objective of this research was to recover the valuable $\mathrm{Rb}$ from SWROC. Before doing this, however, the focus was on recovering Rb from synthetic water having an elevated concentration of $\mathrm{Rb}$. The specific objectives of this study were to: (i) synthesise potassium cobalt hexacyanoferrate $(\mathrm{KCoFC})$ in the laboratory and characterise it; (ii) study the sorption of $\mathrm{Rb}$ in batch and fixed-bed column systems; (iii) determine the effect of co-existing alkali metals ions on Rb sorption; and (iv) assess the desorption of the sorbed $\mathrm{Rb}$ for its recovery.

\section{Material and methods}

\subsection{Preparation of $\mathrm{KCOFC}$}


$\mathrm{KCoFC}$ was produced in the laboratory by mixing one volume of $0.5 \mathrm{M}$ potassium ferrocyanide trihydrate $\left(\mathrm{K}_{4} \mathrm{Fe}(\mathrm{CN})_{6} \cdot 3 \mathrm{H}_{2} \mathrm{O}\right)$ and 2.4 volumes of $0.3 \mathrm{M}$ cobalt nitrate hexahydrate $\left(\mathrm{Co}\left(\mathrm{NO}_{3}\right)_{2} \cdot 6 \mathrm{H}_{2} \mathrm{O}\right)$ [27]. After mixing the suspension for $1 \mathrm{~h}$ at room temperature, it was centrifuged and the precipitate was washed with deionised water. The precipitate was then dried at $115^{\circ} \mathrm{C}$ for $24 \mathrm{~h}$ and the dried material was ground to a particle size of $0.25-0.45 \mathrm{~mm}$, then washed again with deionised water and dried.

\subsection{Feed solutions and chemical analysis}

The feed solution consisted of distilled water spiked with metals to produce solutions of predetermined concentrations. $\mathrm{Rb}, \mathrm{Cs}, \mathrm{Li}, \mathrm{Ca}$ and $\mathrm{Na}$ were added in the form of Analar grade (Sigma-Alrich) $\mathrm{RbCl}, \mathrm{CsCl}, \mathrm{LiCl}, \mathrm{CaCl}_{2}$ and $\mathrm{NaCl}$, respectively. $\mathrm{Rb}, \mathrm{Cs}, \mathrm{K}, \mathrm{Li}, \mathrm{Na}, \mathrm{Ca}$, iron (Fe) and cobalt ( $\mathrm{Co})$ concentrations were determined using Microwave Plasma - Atomic Emission Spectroscopy (MP-AES) (Agilent 4100).

\subsection{Sorbent characterisation}

The chemical composition of $\mathrm{KCoFC}$ was determined by heating $0.05 \mathrm{~g}$ of the material in $1 \mathrm{~mL}$ of $98 \% \mathrm{H}_{2} \mathrm{SO}_{4}$ at $200^{\circ} \mathrm{C}$ for $5 \mathrm{~h}$ according to the procedure used by Nilchi et al. [28]. This was followed by adding $10 \mathrm{~mL}$ of $0.1 \mathrm{M} \mathrm{H}_{2} \mathrm{SO}_{4}$ to the residue and diluting the suspension to $50 \mathrm{~mL}$ with deionised water. The concentrations of $\mathrm{K}, \mathrm{Fe}$ and $\mathrm{Co}$ in the solution were measured after filtration through a $1.2 \mu \mathrm{m}$ syringe membrane filter. The $\mathrm{X}$-ray diffraction (XRD) data of KCoFC powder was obtained on a Siemens D5000 X-ray diffractometer operated with $\mathrm{CuKa}$ radiation and a rotating sample stage; scanning was done at room temperature in the $2 \theta$ angular range of $20-110^{\circ}$. The BET surface area and porosity were measured using a nano-porosity (Mirae SI, South Korea) adsorption analyzer at $77^{\circ} \mathrm{K}$. 
The $\mathrm{pH}$ of $100 \mathrm{~mL}$ suspensions containing $1 \mathrm{~g} / \mathrm{L} \mathrm{KCoFC}$ sorbent was adjusted to different values $(3.0-10.0)$ using $0.1 \mathrm{M} \mathrm{HCl}$ and $0.1 \mathrm{M} \mathrm{NaOH}$. pH measurements were made using a HQ40d portable $\mathrm{pH}$ meter. The suspensions were then agitated for $24 \mathrm{~h}$ in a flat shaker at a shaking speed of $120 \mathrm{rpm}$ at room temperature $\left(24 \pm 1^{\circ} \mathrm{C}\right)$ to investigate the effect of $\mathrm{pH}$ on zeta potential. Zeta potential was measured on a portion of the suspensions using a Zetasizer nano instrument (Nano ZS Zen3600, Malvern, UK) after measuring the pH. Measurements were done in duplicate to minimise undesirable biases (with differences between duplicates always being less than $5 \%$ ).

\subsection{Batch sorption experiments}

The effect of $\mathrm{pH}$ on $\mathrm{Rb}$ sorption was determined by shaking 100 InL soiuuons containing $\mathrm{Rb}$ at $5 \mathrm{mg} / \mathrm{L}$ and $0.5 \mathrm{~g} / \mathrm{L}$ sorbent at different $\mathrm{pHs}$ at room temperature $\left(24 \pm 1^{\circ} \mathrm{C}\right)$ similar to the experiment conducted for measuring zeta potential. The amount of metal sorbed at equilibrium, $\mathrm{q}_{\mathrm{e}}(\mathrm{mg} / \mathrm{g})$, was calculated using Eq. (1):

$$
\mathrm{q}_{\mathrm{e}}=\frac{\left(\mathrm{C}_{0}-\mathrm{C}_{\mathrm{e}}\right) \mathrm{V}}{\mathrm{M}}
$$

where $\mathrm{C}_{0}=$ initial concentration of metal $(\mathrm{mg} / \mathrm{L}) ; \mathrm{C}_{\mathrm{e}}=$ equilibrium concentration of metal $(\mathrm{mg} / \mathrm{L}) ; \mathrm{V}=$ volume of the solution $(\mathrm{L}) ;$ and $\mathrm{M}=$ mass of $\mathrm{KCoFC}(\mathrm{g})$.

Equilibrium metals sorption experiments were conducted in a set of glass flasks containing $100 \mathrm{~mL}$ solutions spiked with $\mathrm{Rb}, \mathrm{Cs}, \mathrm{Na}, \mathrm{Li}$ and $\mathrm{Ca}(5 \mathrm{mg} / \mathrm{L})$ and $\mathrm{KCoFC}$ doses of $0.03-1.0 \mathrm{~g} / \mathrm{L}$ at room temperature $\left(24 \pm 1^{\circ} \mathrm{C}\right)$ and $\mathrm{pH} 7.0$. The suspensions were agitated in a flat shaker at a speed of $120 \mathrm{rpm}$ for $6 \mathrm{~h}, \mathrm{pH}$ adjusted back to 7.0 and agitation continued for $24 \mathrm{~h}$ to ensure that the sorption equilibrium was reached. The percentage of metal sorbed was calculated by dividing the difference between initial and final metal concentrations by the initial metal concentration and multiplying it by 100 . In this study the sorption of all metals was 
investigated using the same initial metal concentration so that their relative sorption capacities could be compared. Our future studies will test the metals' sorption capacities individually and when present in combinations at the concentrations present in SWROC (Table 1)

The experimental results were treated with the Langmuir isotherm model using Eq. (2):

$$
\mathrm{q}_{\mathrm{e}}=\frac{\mathrm{q}_{\max } \mathrm{K}_{\mathrm{L}} \mathrm{C}_{\mathrm{e}}}{1+\mathrm{K}_{\mathrm{L}} \mathrm{C}_{\mathrm{e}}}
$$

All the experiments were duplicated and average values were recorded. The difference between duplicate values was within $\pm 2 \%$.

\subsection{Column sorption experiments}

The fixed-bed column used for the experiments consisted of a Pyrex glass tube where a stainless steel sieve was attached to the bottom followed by a layer of glass beads in order to provide a uniform flow of the solution through the column. A known quantity of GAC (19.8 $\mathrm{g})$ $+\mathrm{KCoFC}(2.2 \mathrm{~g})$ was packed in the column to yield the desired bed height, i.e. $12 \mathrm{~cm}$ (KCoFC content in the column was $10 \%$ of the total column mass). GAC was employed to provide physical stability and good hydraulic conductivity to the columns. Since the batch experiment showed that, of the metals tested, $\mathrm{KCoFC}$ had high sorption capacity only for $\mathrm{Rb}$ and $\mathrm{Cs}$, the column experiments were conducted to determine the competitive effect of only Cs on removing $\mathrm{Rb}$. Therefore, the influent solutions had $\mathrm{Rb}$ only at $5 \mathrm{mg} / \mathrm{L}, \mathrm{Rb}$ at $5 \mathrm{mg} / \mathrm{L}+\mathrm{Cs}$ at 1 $\mathrm{mg} / \mathrm{L}$, and $\mathrm{Rb}$ at $5 \mathrm{mg} / \mathrm{L}+\mathrm{Cs}$ at $5 \mathrm{mg} / \mathrm{L}$. Initial trials showed that $\mathrm{GAC}$ alone as a medium had negligible $\mathrm{Rb}$ adsorption capacity (data reported in Results and Discussion section). Therefore the column's adsorption capacity was assumed to be due to only KCoFC. The metals solutions were pumped through the column at a desired flow velocity $(2.5 \mathrm{~m} / \mathrm{h})$ which was controlled by a peristaltic pump. Effluents at the column's outlet were collected at regular time intervals and 
the $\mathrm{Rb}$ concentration was measured. The breakthrough curves exhibited the loading behaviour of $\mathrm{Rb}$ to be removed from the solution in a fixed-bed column. These curves are usually expressed in terms of adsorbed $R b$ concentration $\left(C_{a d}\right)$, inlet $R b$ concentration $\left(C_{o}\right)$, outlet $R b$ concentration $\left(\mathrm{C}_{\mathrm{t}}\right)$ or normalised concentration defined as the ratio of outlet $\mathrm{Rb}$ concentration to inlet $\mathrm{Rb}$ concentration $\left(\mathrm{C}_{\mathrm{t}} / \mathrm{C}_{\mathrm{o}}\right)$ as a function of number of bed volumes (one bed volume $=$ flow velocity $(\mathrm{m} / \mathrm{h}) *$ time $(\mathrm{h}) /$ bed height $(\mathrm{m}))$. The maximum column capacity, $\mathrm{q}$ total $(\mathrm{mg}$ $\mathrm{Rb}$ ), for a given feed concentration and filtration velocity is equal to the area under the plot of the adsorbed $\mathrm{Rb}$ concentration, $\mathrm{C}_{\mathrm{ad}}\left(\mathrm{C}_{\mathrm{ad}}=\mathrm{C}_{\mathrm{o}}-\mathrm{C}_{\mathrm{t}}\right)(\mathrm{mg} / \mathrm{L})$ versus bed volume. Furthermore it was calculated manually from the breakthrough curves using a Microsoft Excel spreadsheet according to Eq. (3) where Q is the flow rate of the solution $(\mathrm{L} / \mathrm{min})$ :

$$
\mathrm{q}_{\text {total }}=\frac{\mathrm{Q}}{1000} \int_{\mathrm{t}=0}^{\mathrm{t}=\text { total }} \mathrm{C}_{\mathrm{ad}} \mathrm{dt}
$$

\subsection{Desorption of $R b$}

A previous batch desorption study showed that of the following reagents - $0.1 \mathrm{M}$ of $\mathrm{HNO}_{3}$, $\mathrm{KOH}, \mathrm{KCl}, \mathrm{NaCl}, \mathrm{HCl}$, and $\mathrm{NaOH}-0.1 \mathrm{M} \mathrm{KCl}$ was the most efficient in desorbing $\mathrm{Rb}$ [15]. Therefore this reagent was used in the column desorption study. Initially, Rb was saturated on the $\mathrm{KCoFC}$ column containing $10 \% \mathrm{KCoFC}(2.2 \mathrm{~g})$ and $90 \% \mathrm{GAC}(19.8 \mathrm{~g})$ by passing a $\mathrm{Rb}$ solution of $5 \mathrm{mg} / \mathrm{L}$ through the column at a velocity of $2.5 \mathrm{~m} / \mathrm{h}$ until complete breakthrough of $\mathrm{Rb}$ occurred. Then the column was washed with $1600 \mathrm{~mL}$ distilled water at a flow velocity of $2.5 \mathrm{~m} / \mathrm{h}$ to remove $\mathrm{Rb}$ in the column pores followed by leaching with $0.1 \mathrm{M} \mathrm{KCl}$ at a velocity $10 \mathrm{~m} / \mathrm{h}$ for $60 \mathrm{~min}$. The desorbed solutions collected at $13-83$ bed volumes $(10-60 \mathrm{~min})$ were analysed for $\mathrm{Rb}$ to determine the amount of $\mathrm{Rb}$ desorbed. 


\subsection{KCoFC characterisation}

\subsubsection{Chemical decomposition analysis}

Chemical analysis of the acid decomposed $\mathrm{KCoFC}$ showed that the $\mathrm{K}, \mathrm{Fe}$ and Co contents of $\mathrm{KCoFC}$ were $8.4 \%, 7.1 \%$ and $10.13 \%$, respectively. These values are equivalent to 2.14 , 1.27 , and $1.72 \mathrm{mmol} / \mathrm{g}$ of $\mathrm{K}, \mathrm{Fe}$, and $\mathrm{Co}$, respectively. The empirical chemical composition of $\mathrm{KCoFC}$ was calculated by taking the amount of $\mathrm{Fe}$ as one and normalising the amount of Co to this value (mmol $\mathrm{Co} / \mathrm{mmol} \mathrm{Fe})$. Furthermore the amount of $\mathrm{K}$ was calculated by balancing the total number of positive charges in $\mathrm{Fe}, \mathrm{Co}$, and $\mathrm{K}$ to the six negative charges in the $\mathrm{CN}$ group as described by Mimura et al. [29]. The calculation resulted in an empirical chemical composition of $\mathrm{K}_{1.30} \mathrm{Co}_{1.35} \mathrm{Fe}(\mathrm{CN})_{6}$ which is similar to that of: firstly, the composition $\mathrm{K}_{1.34} \mathrm{Co}_{1.33} \mathrm{Fe}(\mathrm{CN})_{6}$ reported for a $\mathrm{KCoFC}$ by Kameník and Šebesta [30]; and secondly, a $\mathrm{KNiFC}\left(\mathrm{K}_{1.45} \mathrm{Ni}_{1.27} \mathrm{Fe}(\mathrm{CN})_{6}\right)$ documented by Mimura et al. [29]. The surface area of $\mathrm{KCoFC}$ was $55.4 \mathrm{~m}^{2} / \mathrm{g}$ with a total pore volume of $0.26 \mathrm{~cm}^{3} / \mathrm{g}$ while the average pore diameter was 18.8 $\mathrm{nm}$. The average pore diameter of $18.8 \mathrm{~nm}$ for the $\mathrm{KCoFC}$ indicates that the material is mesoporous $(2-50 \mathrm{~nm})$.

\subsubsection{Powder X-ray diffraction (XRD) analysis}

The XRD pattern of KCoFC confirmed its crystal structure and the main peaks appeared at the same $2 \theta$ angle, which confirms findings in previous studies for this sorbent synthesised by others and a standard KCoFC (Fig. 1) [18,31]. The sharp peaks detected in the XRD analysis of $\mathrm{KCoFC}$ were at $2 \theta=17.7,25.2,36.1,40.6,43.9$, and 51.2. 


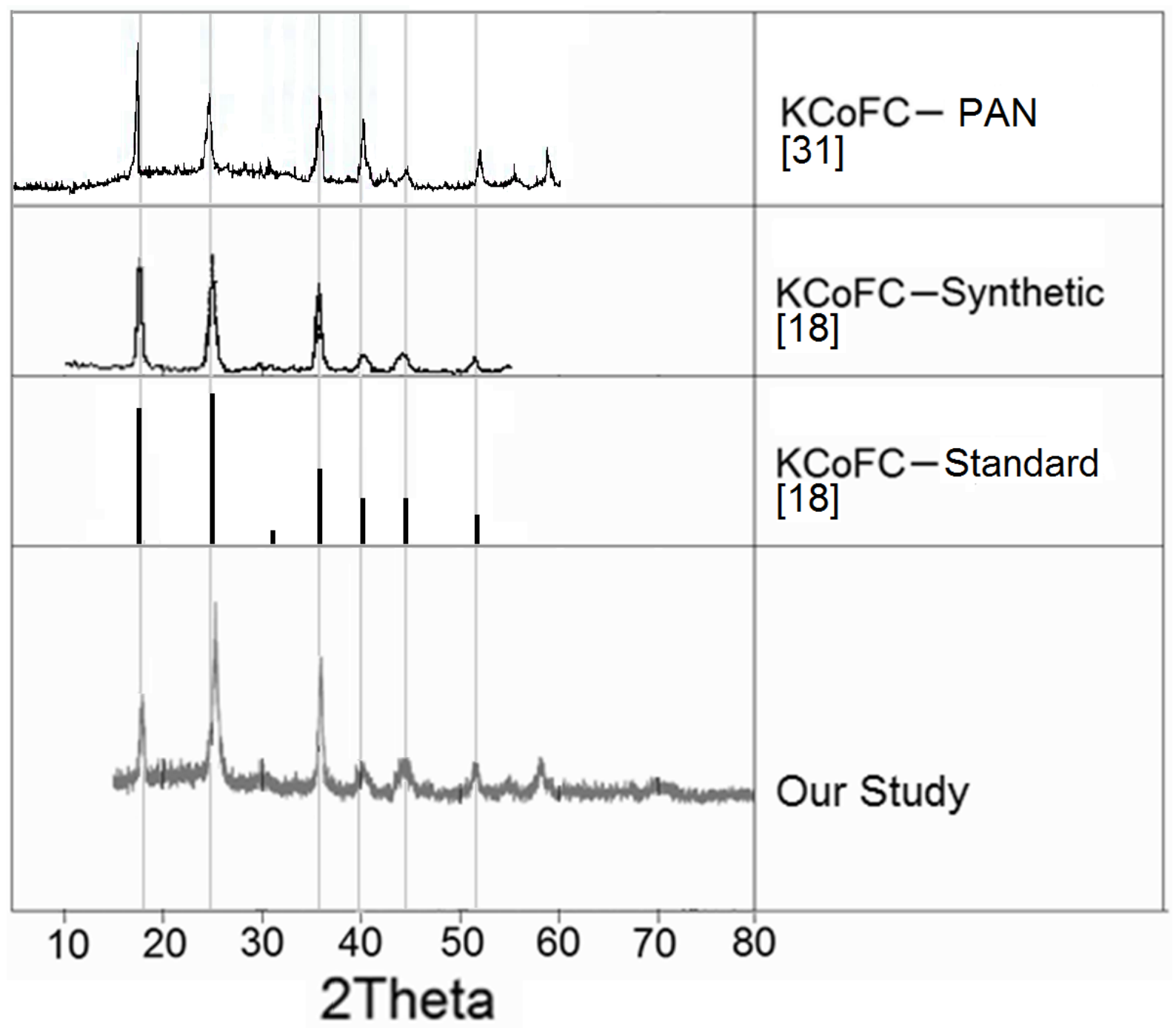

Fig. 1. XRD pattern of KCoFC compared with that of others

\subsection{Batch sorption experiments}

\subsubsection{Effect of $p H$ on zeta potential and $R b$ sorption}

Zeta potential of $\mathrm{KCoFC}$ decreased from -1 to $-15 \mathrm{mV}$ as the $\mathrm{pH}$ increased from 3 to 10 (Fig. 2). This indicates that the number of negative charges on the surface of the sorbent increased with $\mathrm{pH}$. Consistent with the increase in negative charges, $\mathrm{Rb}$ sorption also increased (Fig. 2) as a result of electrostatic adsorption of positively charged $\mathrm{Rb}$ on the negatively charged surface sites. However, at $\mathrm{pH} 3$ when the zeta potential was very low $(\approx-1.7 \mathrm{mV}), \mathrm{Rb}$ sorption 
did not decrease in proportion to the fall in negative zeta potential. This may be due to $\mathrm{Rb}$ sorption arising from exchange with structural $\mathrm{K}$ in the $\mathrm{KCoFC}$ lattice [15].

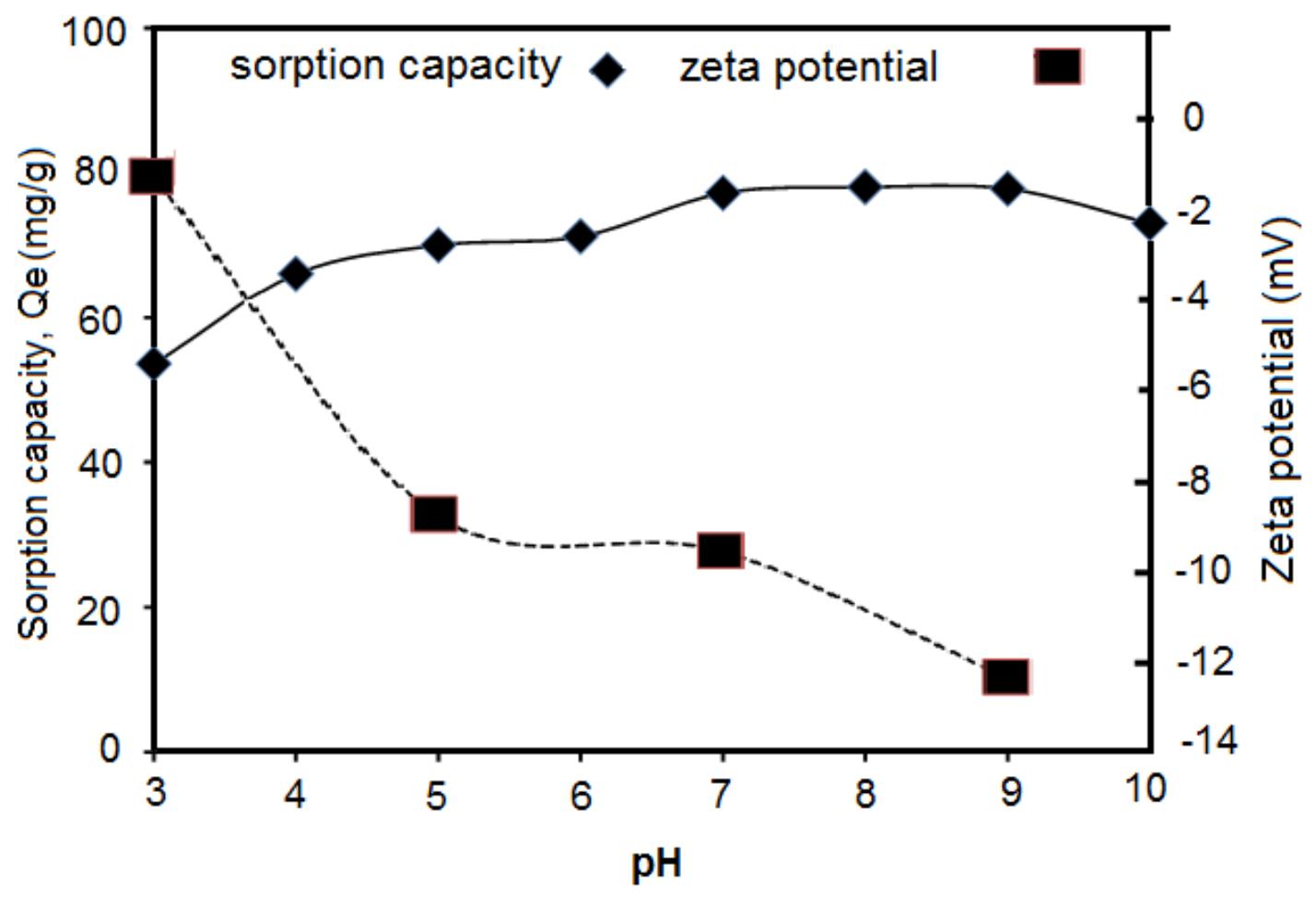

Fig. 2. Effect of $\mathrm{pH}$ on $\mathrm{Rb}$ sorption and zeta potential of $\mathrm{KCoFC}(\mathrm{KCoFC}$ dose $1 \mathrm{~g} / \mathrm{L}$ and initial $\mathrm{Rb}$ concentration $5 \mathrm{mg} / \mathrm{L}$ )

\subsubsection{Sorptive removal efficiencies for $\mathrm{Rb}, \mathrm{Cs}, \mathrm{Li}, \mathrm{Na}$, and $\mathrm{Ca}$}

The KCoFC sorbent demonstrated greater efficiency in removing $\mathrm{Rb}$ and $\mathrm{Cs}$ than $\mathrm{Li}, \mathrm{Na}$ and $\mathrm{Ca}$ at different dosages which ranged from $0.1-1.0 \mathrm{~g} / \mathrm{L}$ for an initial concentration of all metals of $5 \mathrm{mg} / \mathrm{L}$ from a solution volume of $100 \mathrm{~mL}$ (Fig. 3). The maximum removal efficiency was $98-99 \%$ for $\mathrm{Rb}$ and $\mathrm{Cs}$ at the sorbent dose of $1 \mathrm{~g} / \mathrm{L}$, whereas for the other metals it was 2$19 \%$ with $\mathrm{Na}^{+}$having higher sorption capacity than $\mathrm{Li}^{+}$and $\mathrm{Ca}^{2+}$ in accordance with their hydrated ionic radius $\left(\mathrm{Na}^{+} 2.76-3.60 \AA, \mathrm{Li}^{+}\right.$and $\left.\mathrm{Ca}^{2+} 3.40-6.00 \AA\right)$ [15]. The explanation for $\mathrm{Rb}$ and $\mathrm{Cs}$ having higher sorption capacities than $\mathrm{Li}, \mathrm{Na}$, and $\mathrm{Ca}$ is that $\mathrm{Rb}$ and $\mathrm{Cs}$ could penetrate 
the $\mathrm{KCoFC}$ crystal lattice and exchange with structural $\mathrm{K}$ in the body centre of the lattice due to their similar unhydrated ionic radii (Rb $1.48 \AA$, Cs $1.61 \AA$ ) as the cavities within the lattice (1.47 ̊) [15]. Conversely, Na, Li, and Ca with much lower unhydrated radii (0.60-0.99 ̊) were not able to exchange with the structural $\mathrm{K}$ in the lattice. The sorption data for $\mathrm{Rb}$ and $\mathrm{Cs}$ fitted satisfactorily to the Langmuir model $\left(\mathrm{R}^{2}=0.94\right.$ to 0.97$)$ with the sorption capacity of 96 and 61 mg/g, respectively (Fig. 4). This matched the results reported by Petersková et al. [11] for Rb and Cs sorption on potassium hexacyanoferrate sorbent.

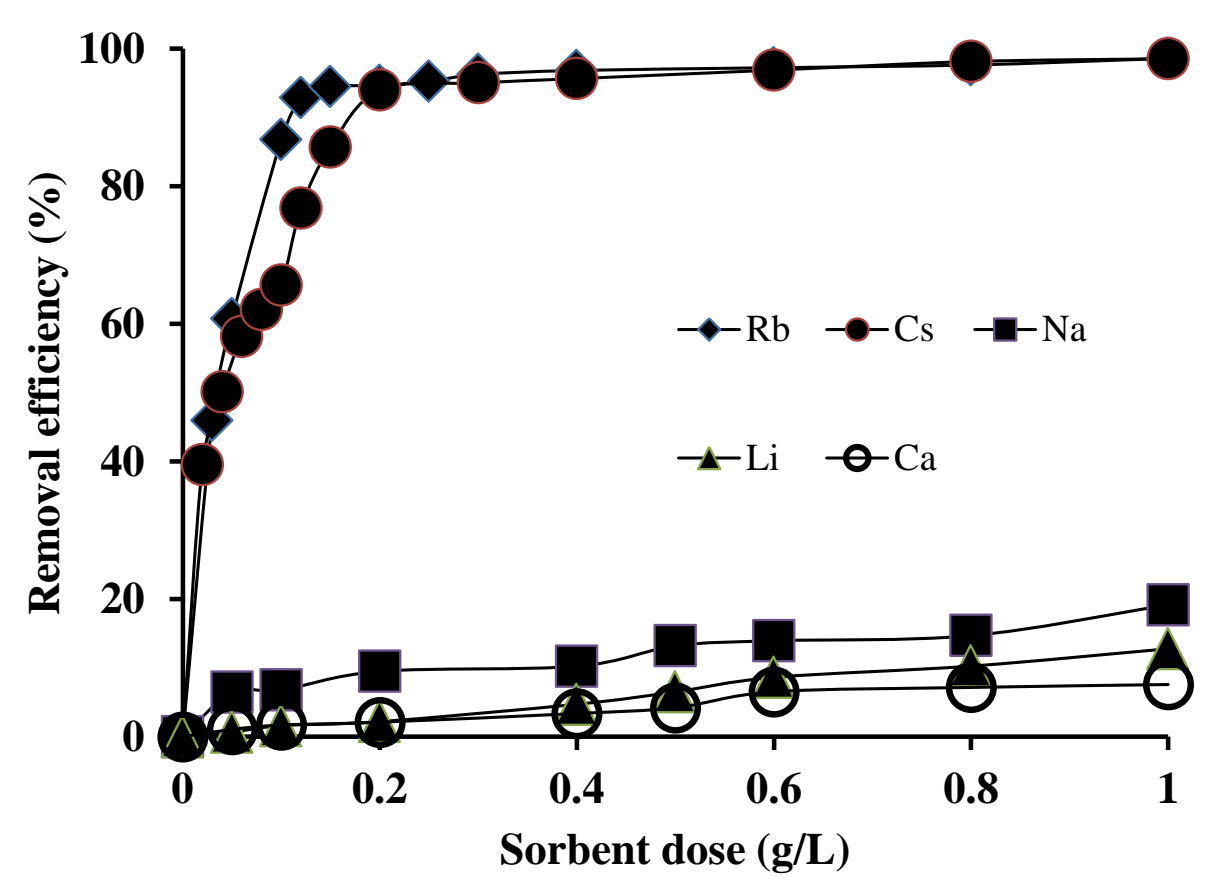

Fig. 3. Effect of $\mathrm{KCoFC}$ dose on the removal of $\mathrm{Rb}, \mathrm{Cs}$, $\mathrm{Li}, \mathrm{Na}$, and $\mathrm{Ca}$ (initial concentration for all metals was $5 \mathrm{mg} / \mathrm{L}$ ). 


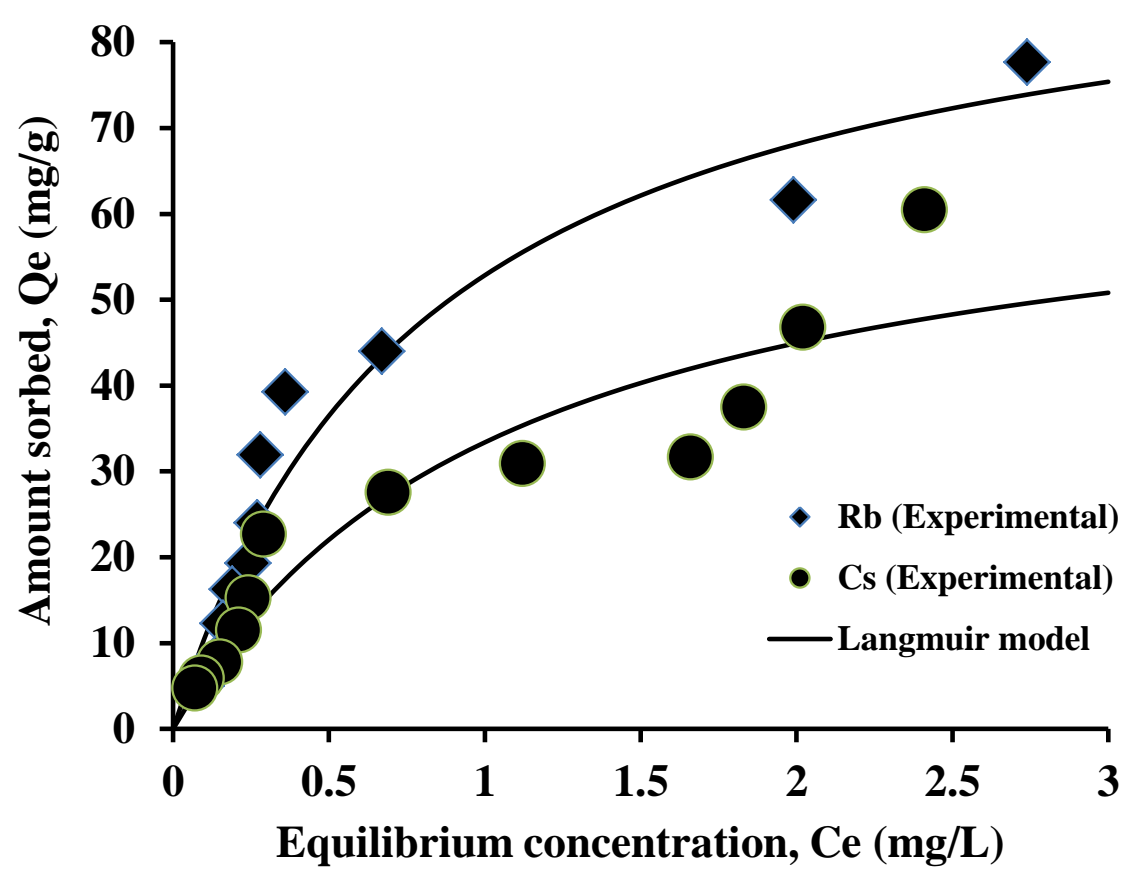

Fig. 4. Langmuir isotherm model (Equation 2) fit to sorption of Rb and Cs on KCoFC. The Langmuir parameters values obtained for the $\mathrm{Rb}$ and $\mathrm{Cs}$ plots were: $\mathrm{K}_{\mathrm{L}}=1.23$ and $1.00 ; \mathrm{q}_{\max }=$ 96 and $61 \mathrm{mg} / \mathrm{g}$; Coefficient of determination $\mathrm{R}^{2}=0.97$ and 0.94 , respectively.

\subsection{Fixed-bed column experiments}

\subsubsection{Breakthrough curves}

Since the batch study showed that KCoFC had the highest sorption capacity for $\mathrm{Rb}$ and Cs, these two metals were chosen for the study using fixed-bed columns. Our hypothesis that GAC has very little sorption capacity for $\mathrm{Rb}$ is confirmed in the fixed-bed column experiment. A complete breakthrough of $\mathrm{Rb}$ did occur when the experiment began in the GAC only column (Fig. 5). Removal of $\mathrm{Rb}$ from aqueous solutions containing $5 \mathrm{mg} \mathrm{Rb} / \mathrm{L}$ by $\mathrm{KCoFC}+\mathrm{GAC}$ column at three initial Cs concentrations $(0,1$ and $5 \mathrm{mg} / \mathrm{L})$ was studied. In the case of $\mathrm{Rb}$ alone in the influent solution the breakthrough curves indicated that there was very little breakthrough of $\mathrm{Rb}$ during the first 50 bed volumes and then the concentration of $\mathrm{Rb}$ in the effluent increased progressively to reach the concentration of the influent (Fig. 5). The rapid breakthrough of $\mathrm{Rb}$ 
was probably due to: firstly, the small amount of $\mathrm{KCoFC}$ in the column (only $2.2 \mathrm{~g}, 10 \%$ of total sorbent mass); and secondly, the low rate of diffusion of $\mathrm{Rb}$ into the $\mathrm{KCoFC}$ lattice for exchange with lattice $\mathrm{K}$. When $\mathrm{Cs}$ was added to $\mathrm{Rb}$ in the influent solution the breakthrough of $\mathrm{Rb}$ was even faster due to $\mathrm{Cs}$ competing with $\mathrm{Rb}$ for sorption.

The results showed that the number of bed volumes required to reach the plateau of $\mathrm{C}_{t} / \mathrm{C}_{0}$ (equal to 0.98 ) was significantly higher (1875) when the solution contained only $\mathrm{Rb}$ than when Cs was present. Furthermore the curve was less steep in the absence of Cs. The sorption capacity of KCoFC from the breakthrough curve of $\mathrm{Rb}$ alone was $61 \mathrm{mg} / \mathrm{g}$, which was among the highest values reported for most adsorbents in the literature for $\mathrm{Rb}[11,22,32]$. However, the adsorption capacity fell to 47 and $42 \mathrm{mg} / \mathrm{g}$ in the presence of Cs at 1 and $5 \mathrm{mg} / \mathrm{L}$, respectively. These results indicate that $\mathrm{Cs}$ had a competitive effect on $\mathrm{Rb}$ sorption. Nonetheless in many situations such as in SWROC, the Cs concentration $(0.0008 \mathrm{mg} / \mathrm{L})$ is much smaller than that of $\mathrm{Rb}$ concentration $(0.19 \mathrm{mg} / \mathrm{L})$ (Table 1$)$ and therefore $\mathrm{Cs}$ is not expected to affect KCoFC's sorption of Rb. 


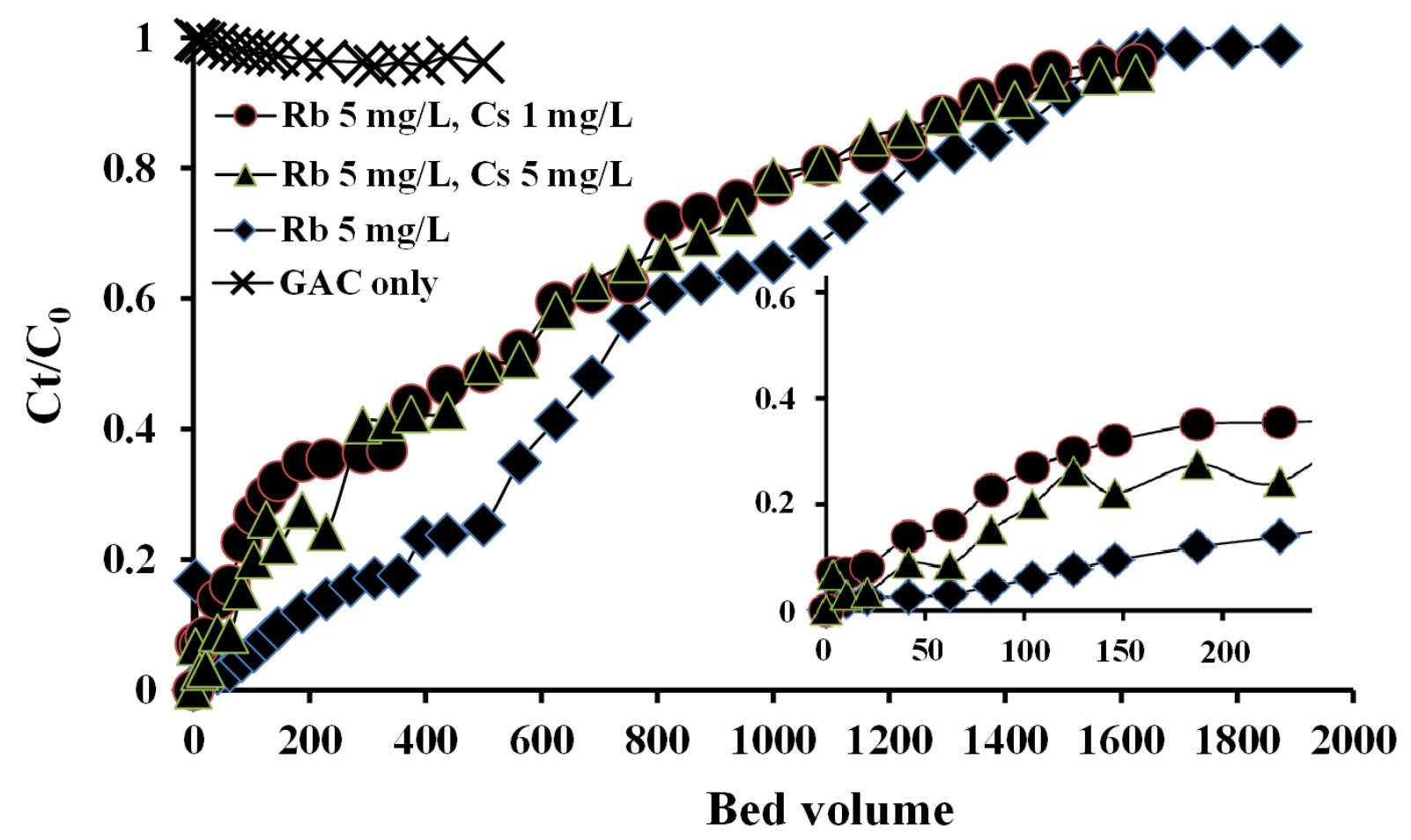

Fig. 5. Breakthrough curves for Rb sorption (filtration velocity $2.5 \mathrm{~m} / \mathrm{h}$, bed height $12 \mathrm{~cm}$ ). The small graph within the large graph is an expanded version of the breakthrough curves up to 250 bed volumes.

Corresponding with the sorption of $\mathrm{Rb}, \mathrm{K}$ release was detected over the sorption's entire duration (Fig. 6) due to $\mathrm{Rb}$ replacing $\mathrm{K}$ from inside the lattice of $\mathrm{KCoFC}$ as described in Equation (4). Naidu et al. [15] reported a ratio of 1:1 of moles of $\mathrm{Rb}$ sorbed to $\mathrm{K}$ release in a batch sorption experiment in accordance with Equation (4):

$$
\mathrm{K}_{1.30} \mathrm{Co}_{1.35} \mathrm{Fe}(\mathrm{CN})_{6}+1.30 \mathrm{Rb}^{+} \rightarrow \mathrm{Rb}_{1.30} \mathrm{Co}_{1.35} \mathrm{Fe}(\mathrm{CN})_{6}+1.30 \mathrm{~K}^{+}
$$

In the current column study, however, the number of moles of K released at any time was equivalent to almost the same number of moles of $\mathrm{Rb}$ sorbed at the first half of the breakthrough curve but less than the number of moles of $\mathrm{K}$ released/mole Rb sorbed for the rest of the curve. 
The lower ratio of $\mathrm{K}$ release to $\mathrm{Rb}$ sorption in the latter part of the curve is probably due to the exhaustion of all the readily exchangeable $\mathrm{K}$ in the $\mathrm{KCoFC}$ structure at easily accessible larger pores of the KCoFC lattice. This allowed $\mathrm{Rb}$ to sorb mainly on the negatively charged surface sites of the sorbent. The more tightly held structural $\mathrm{K}$ was not able to be released unlike in the case of batch mode of sorption [15] because of less turbulent interaction between sorbent particles and solution in the columns. The inability of Rb exchanging with the tightly held lattice $\mathrm{K}$ in column study led to the lower $\mathrm{Rb}$ sorption capacity in the column study $(61 \mathrm{mg} / \mathrm{g})$ compared to the batch study $(96 \mathrm{mg} / \mathrm{g})$ where the turbulent action as well as the residence time of sorbed $\mathrm{Rb}$ were higher. Consistent with these results the cumulative $\mathrm{Rb}$ sorption was 0.71 $\mathrm{mmol} / \mathrm{g}$ compared to cumulative $\mathrm{K}$ release of $0.52 \mathrm{mmol} / \mathrm{g}$ (Fig. $6 \mathrm{~b}$ ).

In contrast to $\mathrm{K}$, very little $\mathrm{Co}$ and $\mathrm{Fe}$ were released during $\mathrm{Rb}$ sorption which indicated that $\mathrm{Rb}$ was not exchanging much with $\mathrm{Co}$ and $\mathrm{Fe}$ in the crystal lattice (Fig. 6). The reason for this is that $\mathrm{Co}$ and $\mathrm{Fe}$ were transitional metal cations bridged through cyano $(\mathrm{CN})$ groups in the lattice structure which could not be easily exchanged with the alkali metal $\mathrm{Rb}$ [33]. 

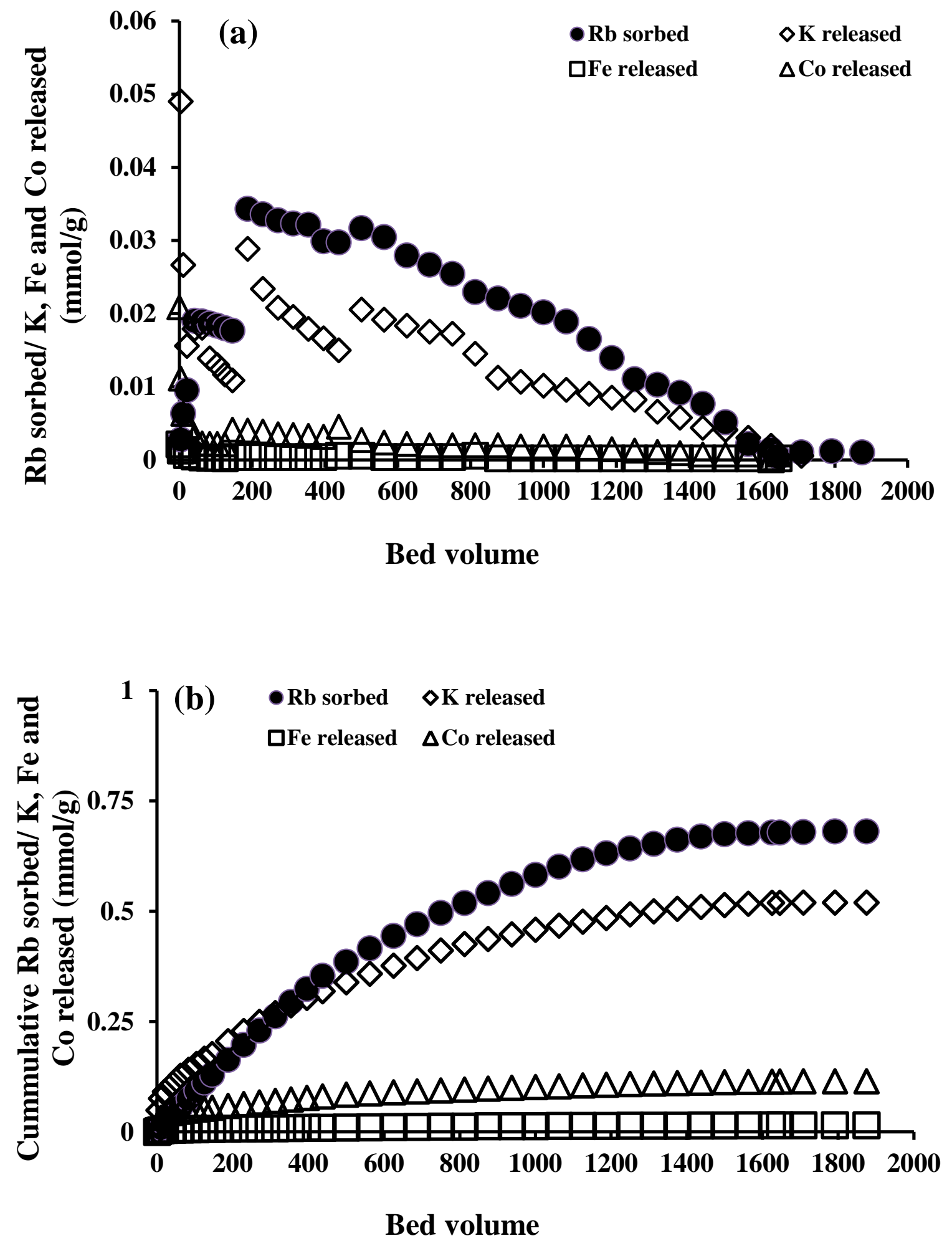

Fig. 6. (a) Individual and (b) cumulative Rb sorbed and $\mathrm{K}, \mathrm{Fe}$, Co released as a function of time in the column experiment (feed $\mathrm{Rb}$ concentration $5 \mathrm{mg} / \mathrm{L}$, filtration velocity $2.5 \mathrm{~m} / \mathrm{h}$ and bed height $12 \mathrm{~cm})$. 


\subsubsection{Rb desorption capacity}

Desorption of $\mathrm{Rb}$ by $0.1 \mathrm{M} \mathrm{KCl}$ indicated that approximately $70 \%$ of $\mathrm{Rb}$ was desorbed within 28 bed volumes (20 min) and by 83 bed volumes (60 min), 99\% was desorbed (Fig. 7). Desorption was more efficient in the column study than in the batch study where only $74 \%$ of the sorbed $\mathrm{Rb}$ was desorbed when $\mathrm{KCoFC}$ was agitated with $50 \mathrm{~mL}$ of $0.1 \mathrm{M} \mathrm{KCl}$ for $30 \mathrm{~min}$. The higher desorption efficiency in the column mode experiment was due to the continuous removal of desorbed $\mathrm{Rb}$ from the column, unlike in the batch mode experiment where the desorbed $\mathrm{Rb}$ remained in contact with the sorbent throughout the process [23].

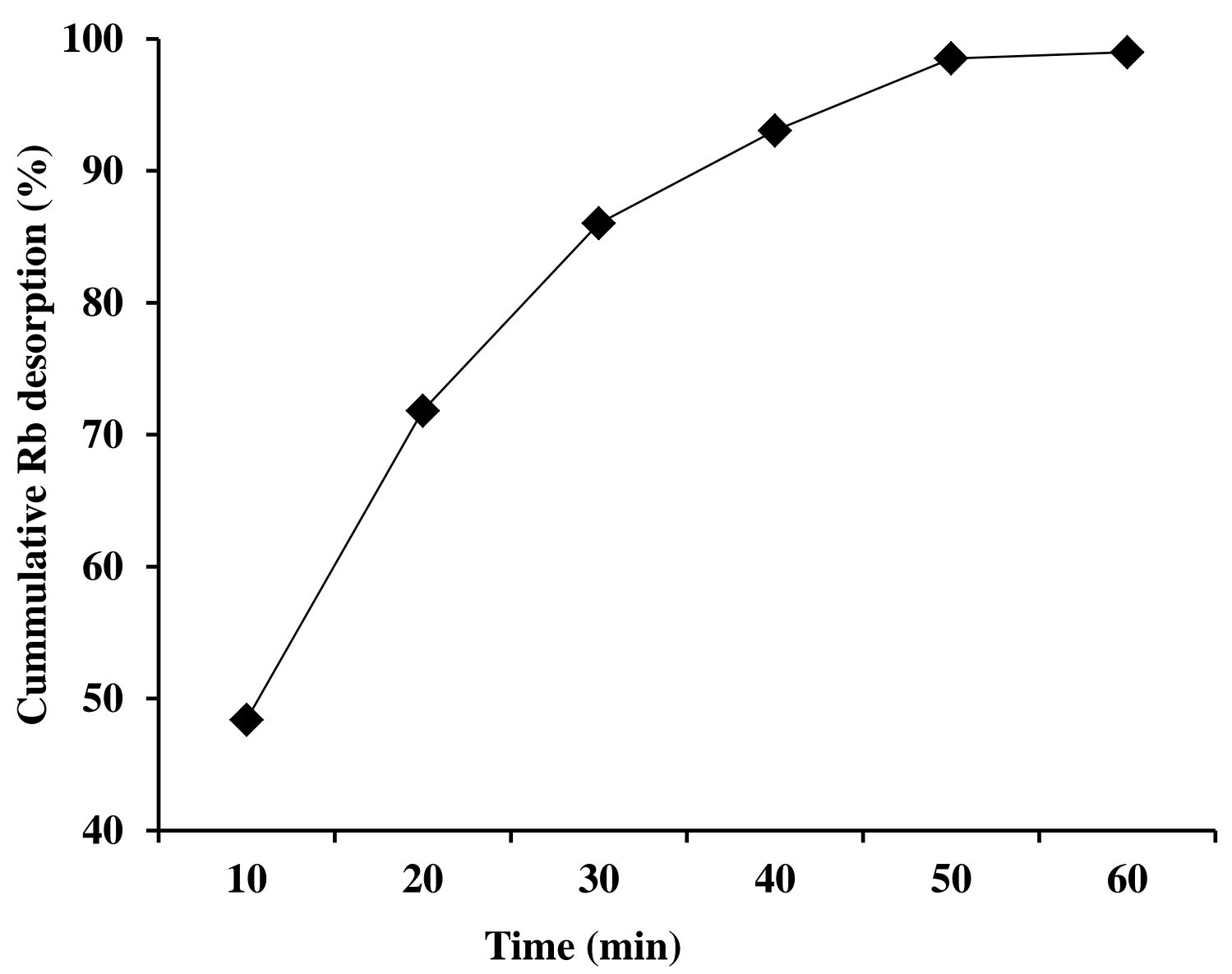

Fig. 7. Cummulative $\mathrm{Rb}$ desorption by $0.1 \mathrm{M} \mathrm{KCl}$ leaching with bed volumes. 


\subsubsection{Practical application of the study}

A further increase of $\mathrm{Rb}$ concentration in SWROC will improve the efficiency in removing $\mathrm{Rb}$. The concentration of metals in SWROC can be increased by employing membrane distillation [34]. Our preliminary experiments have shown that the concentration of $\mathrm{Rb}$ in SWROC from Perth, Western Australia increased from $0.19 \mathrm{mg} / \mathrm{L}$ to $0.79 \mathrm{mg} / \mathrm{L}$ by membrane distillation. Fig. 8 presents a possible procedure for the sustainable recovery of $\mathrm{Rb}$ from SWROC. As an example, a desalination plant of 100,000 $\mathrm{m}^{3} / \mathrm{d}$ capacity can potentially produce $5.9 \mathrm{~kg}$ of recoverable $\mathrm{Rb} /$ day. The recovery of $\mathrm{Rb}$ offset the energy cost of reverse osmosis (RO) and membrane distillation while producing additional clean water and contributing to a brine management solution. 


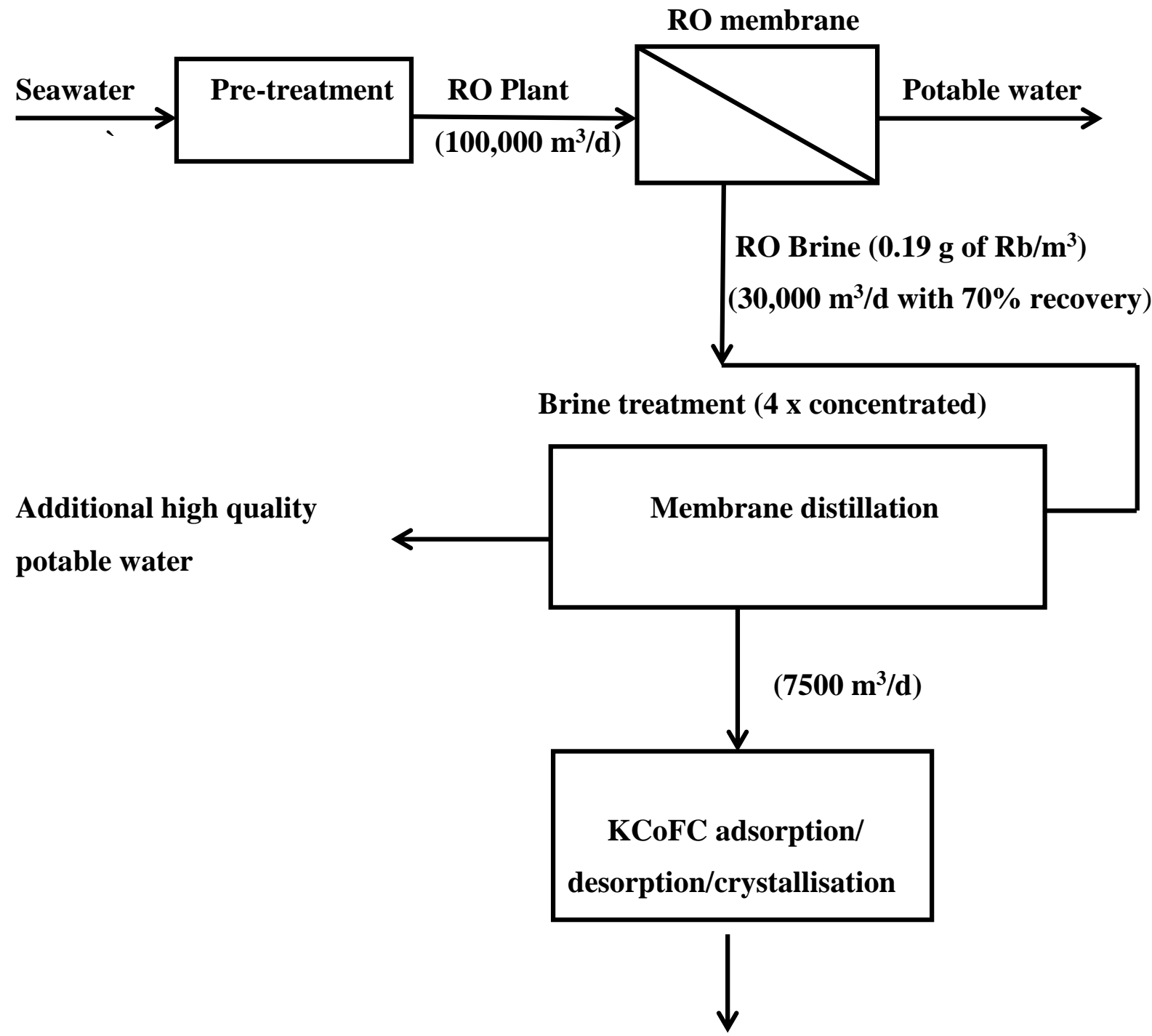

Recoverable Rb

$(5.93 \mathrm{~kg} \mathrm{Rb} / \mathrm{d})$

Fig. 8. Possible procedure for Rb recovery from SWROC

\section{Conclusions}

Batch experimental results at room temperature and $\mathrm{pH} 7$ demonstrated that a laboratory prepared $\mathrm{KCoFC}$ had much higher sorption capacity for $\mathrm{Rb}$ and $\mathrm{Cs}$ than for $\mathrm{Li}, \mathrm{Na}$, and $\mathrm{Ca}$. Langmuir sorption capacities for $\mathrm{Rb}$ and Cs were 96 and $61 \mathrm{mg} / \mathrm{g}$, respectively, which are higher than those reported for many other sorbents. Fixed-bed column studies revealed that Cs 
at concentrations 1 and $5 \mathrm{mg} / \mathrm{L}$ in the feed solution containing $5 \mathrm{mg} / \mathrm{L}$ of $\mathrm{Rb}$ reduced the sorption capacity of $\mathrm{Rb}$. However, Cs concentration in most natural and waste waters such as SWROC is many times smaller than that of $\mathrm{Rb}$ and therefore it is not expected to affect $\mathrm{Rb}$ sorption. Sorbed $\mathrm{Rb}$ was successfully desorbed using $0.1 \mathrm{M} \mathrm{KCl}$. The mechanism of $\mathrm{Rb}$ sorption is one of electrostatic adsorption on the negatively charged surface sites as well as exchange of $\mathrm{K}$ from inside the KCoFC's lattice. A potentially effective procedure for the recovery of $\mathrm{Rb}$ from the SWROC in a typical desalination plant is presented here. It includes a process of membrane distillation of the SWROC to further increase the Rb concentration. Suggestions are also made concerning the amounts of $\mathrm{Rb}$ that can be recovered. Recovered $\mathrm{Rb}$ and additional clean water production not only contribute to offsetting the desalination cost, but also help to improve brine management.

\section{Acknowledgements}

This work was funded by Australian Research Council Discovery Research Grant (DP150101377). We thank Mr. Phillip Thomas in Adelaide, South Australia for proofreading/editing this paper.

\section{References}

[1] A.A. Kaminskii, E. Haussűhl, S. Haussűhl, H.J. Eichler, K. Ueda, J. Hanuza, K. Takaichi, H. Rhee, G.M.A. Gad, $\alpha$-alums: K, Rb, Tl and $\mathrm{NH}_{4} \mathrm{Al}\left(\mathrm{SO}_{4}\right) \cdot 12 \mathrm{H}_{2} \mathrm{O}-$ a new family of $\chi(3)$ - active crystalline materials for Raman laser converters with large frequency shifts, Laser Phys. Lett. 1 (2004) 205-211.

[2] USGS (United States Geological Survey), US Department of the Interior, Mineral Commodity Summaries, 2002.

(http://minerals.usgs.gov/minerals/pubs/commodity/cesium/201302.pdf)

[3] F.S. Wagner, Rubidium and Rubidium Compounds, Enc. Chem. Tech. (2011) 1-11.

[4] W.C. Buttermann, R.G. Reese Jr., Mineral Commodity Profiles Rubidium. U.S. Geological Survey, Open File Report (03-045) (2003) 3-11. 
[5] W. Lenk, H. Prinz, A. Steinmetz, Rubidium and rubidium compounds, Enc. Ind. Chem (2010) 123-126

[6] V.P. Stepanov, L.M. Babushkina, S.I. Dokashenko, Liquid liquid equilibrium in mixtures of lithium fluoride with potassium and rubidium halides, J. Chem. Thermodyn. 51 (2012) 12-16.

[7] J. Jandová, P. Dvořák, H.N. Vu, Processing of zinnwaldite waste to obtain lithium carbonate, Hydrometallurgy 103 (2010) 12-18.

[8] K. Salazar, M.K. McNutt, Metal Prices in the United States Through 2010, U. S. Geological Survey, Reston, Virginia, 2013.

[9] USGS, Mineral Commodity Summaries, 2011.

(http://minerals. usgs. gov/minerals/pubs/commodity/cesium/mcs-2011-rubid.pdf (accessed 10.1.2012)).

[10] Q. Yan, X. Li, Z. Wang, X. Wu, H. Guo, Q. Hu, W. Peng, J. Wang, Extraction of valuable metals from lepidolite, Hydrometallurgy (117-118) (2012) 116-118.

[11] M. Petersková, C. Valderrama, O. Gibert, J.L. Cortina, Extraction of valuable metal ions $(\mathrm{Cs}, \mathrm{Rb}, \mathrm{Li}, \mathrm{U})$ from reverse osmosis concentrate using selective sorbents, Desalination 286 (2012) 316-323.

[12] B. Mohite, S. Burungale, Separation of rubidium from associated elements by solvent extraction with dibenzo-24-crown-8, Anal. Lett. 32 (1999) 173-183.

[13] M. Shamsipur, K. Alizadeh, M. Hosseini, M.F. Mousavi, M.R. Ganjali, PVC Membrane and Coated Graphite Potentiometric Sensors Based on Dibenzo-21-Crown-7 for Selective Determination of Rubidium Ions, Anal. Lett. 38 (2005) 573-588.

[14] J. Le Dirach, S. Nisan, C. Poletiko, Extraction of strategic materials from the concentrated brine rejected by integrated nuclear desalination systems, Desalination 182 (2005) 449-460.

[15] G. Naidu, T. Nur, P. Loganathan, J. Kandasamy, S. Vigneswaran, Selective sorption of rubidium by potassium cobalt hexacyanoferrate, Sep. Purif. Technol. 163 (2016) 238246

[16] A. Ararema, O. Bouras, F. Arbaoui, Adsorption of caesium from aqueous solution on binary mixture of iron pillared layered montmorillonite and goethite, Chem. Eng. J. 172 (2011) 230-236.

[17] H. Yang, L. Sun, J. Zhai, H. Li, Y. Zhao, H. Yu, In situ controllable synthesis of magnetic Prussian blue/graphene oxide nanocomposites for removal of radioactive cesium in water, J. Mater. Chem. A. 2 (2014) 326-332. 
[18] J. Moon, E. Lee, H. Kim, Ion exchange of Cs ion in acid solution with potassium cobalt hexacyanoferrate, Korean J. Chem. Eng. 21 (2004) 1026-1031.

[19] A.M. El-Kamash, Evaluation of zeolite A for the sorptive removal of $\mathrm{Cs}^{+}$and $\mathrm{Sr}^{2+}$ ions from aqueous solutions using batch and fixed bed column operations, J. Hazard. Mater. 151 (2008) 432-445.

[20] R. Saberi, A. Nilchi, S.R. Garmarodi, R. Zarghami, Adsorption characteristic of 137Cs from aqueous solution using PAN-based sodium titanosilicate composite, J. Radioanal. Nucl. 284 (2010) 461-469.

[21] Y. Park, Y. Lee, W.S., Shin, S. Choi, Removal of cobalt, strontium and cesium from radioactive laundry wastewater by ammonium molybdophosphate-polyacrylonitrile (AMP-PAN), Chem. Eng. J. 162 (2010) 685-695.

[22] O. Gibert, C. Valderrama, M. Peterkóva, J.L. Cortina, Evaluation of selective sorbents for the extraction of valuable metal ions $(\mathrm{Cs}, \mathrm{Rb}, \mathrm{Li}, \mathrm{U})$ from reverse osmosis rejected brine, Solvent Extr. Ion Exch. 28 (2010) 543-562.

[23] P. Loganathan, S. Vigneswaran, J. Kandasamy, N.S. Bolan, Removal and recovery of phosphate from water using sorption, Crit. Rev. Env. Sci. Tech. 44 (2014) 847-907.

[24] S. Taj, D. Muhammad, M.A. Chaudhury, M. Mazhar, Lithium, rubidium and cesium ion removal using potassium iron (III) hexacyanoferrate (II) supported on polymethylmethacrylate, J. Radioanal. Nucl. Chem. 288(1) (2011) 79-88.

[25] X.S. Ye, Z.J. Wu, W. Li, H.N. Liu, Q. Li, B.J. Qing, M. Guo, F. Go, Rubidium and cesium ion adsorption by an ammonium molybdophosphate-calcium alginate composite adsorbent, Colloids Surf. A 342(1-3) (2009) 76-83.

[26] D.P. Sounthararajah, P. Loganathan, J. Kandasamy, S. Vigneswaran, Column studies on the removal of dissolved organic carbon, turbidity and heavy metals from stormwater using granular activated carbon, Desalin. Water Treat. 57 (2016) 5045-5055.

[27] W. Prout, E. Russell, H. Groh, Ion exchange absorption of cesium by potassium hexacyanocobalt (II) ferrate (II), J. Inorg. Nucl. Chem. 27 (1965) 473-479.

[28] A. Nilchi, B. Malek, M.G. Maragheh, A. Khanchi, Investigation of the resistance of the potassium copper nickel hexacyanoferrate (II) ion exchanger against gamma irradiation, Radiat. Phys. Chem. 68 (2003) 837-842.

[29] H. Mimura, M. Kimura, K. Akiba, Y. Onodera, Selective Removal of Cesium from Sodium Nitrate Solutions by Potassium Nickel Hexacyanoferrate-Loaded Chabazites, Separ. Sci. Technol. 34(1) (1999) 17-28.

[30] J. Kameník, F.Šebesta, Comparison of some commercial and laboratory prepared caesium ion-exchangers, Czech. J. Phys. 53 (2003) A571-A576. 
[31] A. Nilchi, A. Khanchi, H. Atashi, A. Bagheri, L. Nematollahi, The application and properties of composite sorbents of inorganic ion exchangers and polyacrylonitrile binding matrix, J. Hazard. Mater. A137 (2006) 1271-1276.

[32] A.K. Jain, R. Singh, C. Bala, On the sorption behaviour of some cations on cobalt hexacyanoferrate (III) exchanger. Binary separations of $\mathrm{Rb}^{+}$and $\mathrm{Cs}^{+}$on columns, Bull. Chem. Soc. Jpn. 56 (1983) 1269-1270.

[33] C. Loos-Neskovic, S. Ayrault, V. Badillo, B. Jimenez, E. Garnier, M. Fedoroff, D. Jones, B. Merinov, Structure of copper-potassium hexacyanoferrate (II) and sorption mechanisms of cesium, J. Solid State Chem. 177 (2004) 1817-1828.

[34] G. Naidu, S. Jeong, Y. Choi, E. Jang, T. Hwang, S. Vigneswaran, Application of vacuum membrane distillation for small scale drinking water production, Desalination. 354 (2014) 53-61. 